\title{
NEW LAYOUT OF THE MAIN NETWORK IN THE VYSOČINA REGION
}

\author{
Martin Černý, Jaroslav Jánský, Ondřej Prchal*
}

\begin{abstract}
The aim of this contribution is to define the backbone road network of the Vysočina Region and to introduce a system of road management to this network. The determination of the extent of the backbone road network is based on multi-criterion decision-making methods, with traffic as the basic parameter for defining the backbone road network. This is referred to as the number of vehicles passing through that section for a specified period of time. Vehicles are further divided into categories according to their size. A new backbone road network layout is designed to better reflect the current situation. In addition, a road management system is in place for the costs that need to be incurred with regard to the nature of maintenance and repairs. The article does not refer to the division of these costs; it only refers to the problem. It is precisely the efficiency of spending on the infrastructure maintenance of the means of transport that has become a frequent topic of discussion in the assessment of the management of the individual road network owners. Quality, safety, and reliability of transport infrastructure are also a limiting factor for attracting significant investment into the regions and the socio-demographic aspects of the territory. The article analyses the road network from the point of view of traffic intensity. This assessment is most used in patch planning; therefore, a major part of the article is devoted to it. Part of the contribution is also devoted to the issue of public transport on this road network. Public transport is strongly linked to transport infrastructure and is often a crucial factor in planning, especially winter maintenance on lower-class roads. The quality and efficiency of the road network must be seen as a compact unit, which directly or indirectly affects the functioning of all institutions and citizens in the territory concerned.
\end{abstract}

Keywords: backbone road network, road management system, multi-criteria decision making JEL Classification: X12

\section{Introduction}

Increasing the efficiency of spending public budgets is a long-term and endless process. Budget appropriations are limited and it is not possible to cover the extent of a road network in the area of road infrastructure with sufficient quality. This is due to the existing internal debt, i.e. underfinancing of expenditure. It is essential to define the core backbone

* University of Economics, Prague, Faculty of Management (jansky@fm.vse.cz). 
network and to continue to operate systemically in the long term with this network and to introduce a road management system. Multi-criteria decision-making methods can be used to implement the road management system. Traffic intensity is the basic parameter for defining the backbone road network.

\section{Literature Review}

Dvorák (2008) addresses the issues of the public budget and the deficit of public finances. Literature research and the latest findings by Kruntorádová (2015) deals with the issue of financing Czech cities, which concerns, among other items, transport and infrastructure. Abraham (2014) focuses on sustainable development with regard to environmental aspects that often limit its development and improvement. Jazcilevich et al. (2015) also analyse the economic and environmental impacts of transport and the possibilities of development. Koblížek (2016) examines the issue of passenger transport, namely the demand for bus transport in regions where, especially in those with lower population density, this mode of transport is a possible solution to the current issue. Pawlasová (2015) addresses the issue of satisfaction with public transport services provided both within basic transport services and beyond, i.e. within the commercially provided transport. Sachs (2015) deals with sustainable development in the context of technological change in the 21st Century. Solecka and Żak (2014) are focused on integrated transport systems and transport simulation. The simulation of traffic loads is an important aspect in planning the development of the communications network, which is not only about the construction but also the reconstruction of the existing roads when their units or their status often do not meet the demands of today. Sellers et al. (2017), in their most recent publication, address the problem of a new trend in public administration, which is the governance that strongly affects transport issues. The new trends deserve major attention as they have the potential to completely change the paradigms of the individual fields and to ensure greater efficiency of the expended funds. Janatka (2017) examines the issue of business in a globalised world that brings many changes compared to existing habits. It is precisely the process of globalisation that is closely related to the transport issue, which is the cornerstone of these changes along with the development of communication technologies.

In particular, articles on public-private partnerships are of particular interest to new issues published in professional journals. PPP projects are one way of helping to improve the infrastructure that is often in an unsatisfactory condition without major pressure on public budgets. These issues are addressed by Heinen et al. (2015) and Roumboutsos, Voordijk and Pantelias (2015). These authors describe the possibilities of financing large-scale construction projects using the PPP method to accelerate the construction and development of the site concerned. Besides its own principle of the functioning of this model of cooperation, the articles describe the risk for each version and other aspects of this form of cooperation between the public and private sector. The subject of the problem is also described by Roumboutsos, Voordijk and Pantelias (2015). The problems of transport and its related aspects are further solved by Dubrovsky, Yaroshevich and Kuzmin (2016), who deal with the operational efficiency of transport companies with regard to the condition of transport infrastructure and its quality and density, which have consequences 
for other interested economic subjects. Newman and Kenworthy (2015) examine the possibilities of planning new transport routes and infrastructure in general with regard to its sustainability in the context of future development. The environmental impacts that transport infrastructure brings are not only positive, but also have to take into account the negative impact on the environment and other aspects, which is addressed by Matas, Raymond and Roig (2018).

From the new articles, the authors of the University of Poznań, specifically Myczko et al. (2017), focus on the negative impacts of road transport, especially mortality and other negative effects on road users and the surroundings. Behrends (2017) addresses the issue of the relationship between road and rail transport. It is the mutual interdependence of the systems that is a potential form of development in Vysočina. Simoni and Claudel (2017) deal with the possibility of simulating the traffic load, which is closely related to this paper dealing with transport in the region of Vysočina. They describe the intensity of traffic as a simulation in future years. Strategic planning in public administration, which is very closely related to the issue, is dedicated to Krbová (2016). This area has long been neglected in the Czech Republic with many of these areas now being instituted.

\section{Methodological Approach}

For the regional road network, it is important to know the intensity of traffic on II. and III. class roads. As part of the national census, 6,521 census points were established and 1,250 censuses were selected as part of the planned census in the Vysočina Region on II. and III. class roads. It is essential to analyse the issues both from the point of view of the total traffic intensity and its partial analysis of the individual sections of the road linking the regional seat in terms of vehicle types and the load of the road. Terrestrial communications, mainly used for economic purposes, will have a higher load on heavy goods vehicles than roads that will have a higher intensity of passenger cars and will serve primarily for social purposes or for socio-economic purposes, e.g. from the point of view of commuting. The load on the road has a major impact on the technological progress of the modernisation of the road network.

The solution to the choice of road network with regard to the introduction of a roadtraffic management system will focus on two aspects. The first point solely concerns the intensity of the total of all vehicles and the intensity of trucks. The second point concerns the verification of the individual cycles of road management in terms of technological progress in the various phases of the economic cycle. Here, the key parameter is the Heavy Goods Vehicle (TNV), which is a recalculated value and, from the point of view of the technical standards, is indicative of determining, for example, the type of road surface cover. Heavy motor vehicles are the only key input parameter for determining the life of the road. 
Table 1 | Abbreviations used in the census

\begin{tabular}{|l|l|}
\hline \multicolumn{2}{|l|}{ Abbreviations used } \\
\hline LN & Lightweight trucks (payload up to 3.5t) with or without trailers \\
\hline SN & Medium Cargo Trucks (payload $3.5-10$ t) without trailers \\
\hline SNP & Medium lorries (payload 3.5 - 10t) with trailers \\
\hline TN & Heavy goods vehicles (payload over 10t) without trailers \\
\hline TNP & Heavy goods vehicles (payload over 10t) with trailers \\
\hline NSN & Semitrailers for trucks \\
\hline A & Buses \\
\hline AK & Articulated buses \\
\hline TR & Tractors without trailers \\
\hline TRP & Tractors with trailers \\
\hline TV & Heavy motor vehicles in total \\
\hline O & Passenger cars and vans with and without trailers \\
\hline M & Single-track motor vehicles \\
\hline SV & All motor vehicles in total (sum of vehicles) \\
\hline TNV & Heavy goods vehicles (0.1.LN $+0.9 . S N+1.9 . S N P+$ TN $+2.0 . T N P+2.3 . N S N+$ A + AK) \\
\hline PS & $\begin{array}{l}\text { The ratio of the intensity of the opposite traffic flow during the Sunday (afternoon) return } \\
\text { peak }\end{array}$ \\
\hline
\end{tabular}

Source: (DNRM, 2016)

The draft measures will be based on multi-criteria decision making, which takes into account the other variables that ensure the availability and interdependence of social and economic characteristics.

Table 2 shows the roads on the backbone network with the road marking and the interconnection of municipalities on the given road. The roadway designation links do not always connect to all the sites, for example, because there are two roads in front of the village, and there is only one road in the village. Nevertheless, from the point of view of the evaluation of the characteristics of the social factors in particular, the road is led by a sign between the municipalities. Furthermore, for example, by interconnecting municipalities on a given road, there is a certain short stretch following a high-order road - class I roads. In this case, there is also a road sign in one section between individual municipalities. 
Table 2 | The backbone road network of the Vysočina Region

\begin{tabular}{|c|c|}
\hline \multicolumn{2}{|c|}{ The backbone road network } \\
\hline \multicolumn{2}{|c|}{ Larger settlements on the road to the backbone network } \\
\hline $\mathrm{II} / 128$ & Černovice, Pacov, Salačova Lhota, Lukavec \\
\hline $11 / 409$ & Černovice, Kamenice nad Lipou, Žirovnice, Počátky \\
\hline $11 / 132$ & Počátky, Horní Cerekev \\
\hline $\mathrm{II} / 112$ & Telč, Horní Cerekev, Pelhřimov, Červená Řečice, Košetice \\
\hline $11 / 406$ & Border of the region, Telč, Třešt', Kostelec \\
\hline $11 / 602$ & Pelhřimov, Jihlava, Velké Meziříčí, Velká Bíteš \\
\hline $11 / 130$ & Křelovice, Senožaty, Koberovice, Ledeč nad Sázavou, Golčův Jeníkov \\
\hline $11 / 345$ & Golčův Jeníkov, Chotěboř, \\
\hline $11 / 344$ & Chotěboř, Dolní Krupá, Havlíčkův Brod \\
\hline $\mathrm{II} / 150$ & Ledeč nad Sázavou, Světlá nad Sázavou, Havlíčkův Brod \\
\hline $11 / 347$ & Světlá nad Sázavou, Humpolec \\
\hline $11 / 405$ & Jihlava, Třebíč \\
\hline $11 / 360$ & Moravec, Křižanov, Velké Meziříčí, Třebíč, Jaroměřice nad Rokytnou \\
\hline $11 / 360$ & Nové Město na Moravě, Jimramov, border of the region \\
\hline II/152 & Jaroměřice nad Rokytnou, Moravské Budějovice, Jemnice \\
\hline $11 / 408$ & Jemnice -border of the region \\
\hline $\mathrm{II} / 410$ & Jemnice-border of the region \\
\hline $\mathrm{II} / 152$ & Jaroměřice nad Rokytnou, Hrotovice, border of the region \\
\hline $11 / 399$ & Třesov, Dalešice, Rouchovany, border of the region \\
\hline $11 / 399$ & Náměšt' nad Oslavou, Jinošov, Velká Bíteš \\
\hline $11 / 379$ & Velká Bíteš -border of the region \\
\hline $11 / 357$ & Bystřice nad Pernštejnem, Dalečín, Jimramov \\
\hline $11 / 387$ & Štěpánov nad Svratkou, border of the region \\
\hline $11 / 345$ & Chotěboř, Ždírec nad Doubravou \\
\hline $11 / 352$ & Jihlava, Polná \\
\hline $11 / 351$ & Polná, Přibyslav \\
\hline III/3507 & Přibyslav, Havlíčková Borová, Ždírec nad Doubravou \\
\hline
\end{tabular}

Source: (Ksusv.cz, 2015)

Size is important in terms of the interconnection of settlements. The table below shows the population as of January 1, 2017 of larger settlements on the backbone road network. There is always a large settlement on a given road. According to the density of settlements in the Vysočina Region, which is a typical rural area, there is also the distribution 
of significant settlements on the road network, which is quite different from the point of view of the mentioned settlements. It is necessary to always take the specific road into account.

\section{Table 3 | Settlements on the backbone road network}

\begin{tabular}{|c|c|}
\hline Road & $\begin{array}{l}\text { Municipalities along the route (the number of inhabitants as at January 1, } 2017 \\
\text { are in parentheses) }\end{array}$ \\
\hline II/128 & Černovice (1 728), Pacov (4 871), Salačova Lhota (130), Lukavec (988) \\
\hline $11 / 409$ & Černovice (1 728), Kamenice nad Lipou (3 791), Žirovnice (2 915), Počátky (2 563) \\
\hline II/132 & Počátky (2 563), Horní Cerekev (1 840) \\
\hline II/112 & $\begin{array}{l}\text { Telč (5 410), Horní Cerekev (1 840), Pelhřimov (16 044), Červená Řečice (1 017), } \\
\text { Košetice (708) }\end{array}$ \\
\hline $11 / 406$ & Telč (5 410), Třešt' (5 793), Kostelec (905) \\
\hline II/602 & Pelhřimov (16 044), Jihlava (50 559), Velké Meziříčí (11 593), Velká Bíteš (5 137) \\
\hline II/130 & $\begin{array}{l}\text { Křelovice (359), Senožaty (729), Koberovice (159), Ledeč nad Sázavou (5 151), } \\
\text { Golčův Jeníkov (2 639) }\end{array}$ \\
\hline II/345 & Golčův Jeníkov (2 639), Chotěboř (9 343) \\
\hline II/344 & Chotěboř (9 343), Dolní Krupá (420), Havlíčkův Brod (23 145) \\
\hline II/150 & Ledeč nad Sázavou (5 151), Světlá nad Sázavou (6 637), Havlíčkův Brod (23 145) \\
\hline II/347 & Světlá nad Sázavou (6 637), Humpolec (10 850) \\
\hline II/405 & Jihlava (50 559), Třebíč (36 330) \\
\hline II/360 & $\begin{array}{l}\text { Moravec (623), Křižanov (1 857), Velké Meziříčí (11 593), Třebíč (36 330), } \\
\text { Jaroměřice nad Rokytnou (4 181) }\end{array}$ \\
\hline II/360 & Nové Město na Moravě (10 110), Jimramov (1 186) \\
\hline II/152 & Jaroměřice nad Rokytnou (4 181), Moravské Budějovice (7 441), Jemnice (4 075) \\
\hline $11 / 408$ & Jemnice (4 075) \\
\hline II/410 & Jemnice (4 075) \\
\hline II/152 & Jaroměřice nad Rokytnou (4 181), Hrotovice (1 770) \\
\hline II/399 & Třesov (88), Dalešice (604), Rouchovany (1 187) \\
\hline II/399 & Náměšt' nad Oslavou (4 871), Jinošov (226), Velká Bíteš (5 137) \\
\hline II/379 & Velká Bíteš (5 137) \\
\hline $11 / 357$ & Bystřice nad Pernštejnem (8 202), Dalečín (649), Jimramov (1 186) \\
\hline II/387 & Štěpánov nad Svratkou (709) \\
\hline $11 / 345$ & Chotěboř (9 343), Ždírec nad Doubravou (3 143) \\
\hline II/352 & Jihlava (50 559), Polná (5 134) \\
\hline II/351 & Polná (5 134), Přibyslav (4 022) \\
\hline III/3507 & Přibyslav (4 022), Havlíčková Borová (954), Ždírec nad Doubravou (3 143) \\
\hline
\end{tabular}

Source: (Černý, 2015) 
Tables 4 and 5 show the characteristics of the traffic intensities of the total vehicles and heavy-duty vehicles.

Table 4 | Intensity of total SV vehicles

\begin{tabular}{|c|c|c|}
\hline \multicolumn{2}{|c|}{ Frequency of traffic intensity } & \multirow{2}{*}{$\begin{array}{l}\text { Variability of traffic intensity - SV } \\
\text { From I/19 Lukavec to Pacov a total of } 1106 \text { vehicles } \\
\text { (909 heavy-duty, } 192 \text { passenger cars); in Pacov } \\
6873 \text { vehicles in total ( } 859 \text { heavy-duty, } 5979 \text { passenger } \\
\text { cars); from Pacov to split II/124 a total of } 1186 \text { vehicles } \\
\text { ( } 379 \text { heavy-duty, } 1775 \text { passenger cars), further from } \\
\text { the division with II/124 to Čáslavsko, a total of } 1154 \text { vehicles } \\
\text { (221 heavy-duty, } 921 \text { passenger cars). }\end{array}$} \\
\hline $\mathrm{II} / 128$ & $\begin{array}{l}\text { Černovice, Pacov, } \\
\text { Salačova Lhota, } \\
\text { Lukavěc }\end{array}$ & \\
\hline $11 / 409$ & $\begin{array}{l}\text { Černovice, Kamenice } \\
\text { nad Lipou, Žirovnice, } \\
\text { Počátky }\end{array}$ & $\begin{array}{l}\text { From the disconnection from II/398 to Rancířov no } \\
\text { measurements were made; ranging from Rancířov to } \\
\text { Slavonice } 599 \text { vehicles ( } 71 \text { heavy-duty, } 508 \text { passenger cars, } \\
\text { from Slavonice to connection to II/153 a total of } 683 \text { vehicles } \\
\text { ( } 82 \text { heavy-duty, } 596 \text { passenger cars); from Markvarec to } \\
\text { the connection with II/408 was not a measurement section; } \\
\text { from the connection with II/408 to I/23 a total of } 897 \text { vehicles } \\
\text { (136 heavy-duty, } 755 \text { passenger cars). }\end{array}$ \\
\hline $\mathrm{II} / 132$ & Počátky, Horní Cerekev & $\begin{array}{l}\text { From Jarošov nad Nežárkou to Žirovnice a total } \\
\text { of } 1486 \text { vehicles ( } 240 \text { heavy-duty, } 1232 \text { passenger cars); } \\
\text { in Žirovnice a total of } 3310 \text { vehicles ( } 560 \text { heavy-duty, } \\
2717 \text { passenger cars); from Žirovnice to Počátky a total } \\
\text { of } 2925 \text { vehicles ( } 436 \text { heavy-duty, } 2466 \text { passenger cars); } \\
\text { in Počátky a total of } 3307 \text { ( } 482 \text { heavy-duty, } 2798 \text { passenger } \\
\text { cars); from Počátky to Horní Cerekev } 1413 \text { vehicles } \\
\text { (172 heavy-duty, } 1214 \text { passenger cars). }\end{array}$ \\
\hline $\mathrm{II} / 112$ & $\begin{array}{l}\text { Telč, Horní Cerekev, } \\
\text { Pelhřimov, Červená } \\
\text { Řečice, Košetice }\end{array}$ & $\begin{array}{l}\text { From the beginning (from crossroad II/410) to Nová Říše } \\
\text { the section is not measured; from Nová Říše to Telč } \\
1145 \text { vehicles ( } 150 \text { heavy-duty, } 978 \text { passenger cars); } \\
\text { in Telč } 4391 \text { vehicles ( } 716 \text { heavy-duty, } 3633 \text { passenger } \\
\text { cars); from Telč to Nová Ves a total of } 1022 \text { vehicles } \\
\text { ( } 269 \text { heavy-duty, } 743 \text { passenger cars); from Nová Ves } \\
\text { to Horní Cerekev, there is no section measured; in Horní } \\
\text { Cerekev a total of } 2497 \text { vehicles ( } 358 \text { heavy-duty, } \\
2126 \text { passenger cars); Horní Cerekev in Nové Buky } \\
2497 \text { vehicles in total ( } 358 \text { heavy-duty, } 2126 \text { passenger } \\
\text { cars); from Nové Buky to Pelhřimov } 2645 \text { vehicles } \\
\text { ( } 613 \text { heavy-duty, } 2021 \text { passenger cars). }\end{array}$ \\
\hline $11 / 406$ & $\begin{array}{l}\text { Border of the region, } \\
\text { Telč, Třešt', Kostelec }\end{array}$ & $\begin{array}{l}\text { From the border of Telč to Telč } 2841 \text { vehicles } \\
\text { ( } 372 \text { heavy-duty, } 2446 \text { passenger cars); in Telč } \\
4391 \text { vehicles ( } 716 \text { heavy-duty, } 3633 \text { passenger cars); } \\
\text { from Telč to Třešt' } 3642 \text { vehicles ( } 533 \text { heavy-duty, } \\
3094 \text { passenger cars), } 8949 \text { in Třešt' ( } 965 \text { heavy-duty, } \\
7916 \text { passenger cars); from Třešt' to connection II/613 total } \\
5517 \text { vehicles ( } 665 \text { heavy-duty, } 4810 \text { passenger cars); from } \\
\text { connection II/613 to connection in II/603 } 9277 \text { vehicles } \\
\text { (1073 heavy-duty, } 8103 \text { passenger cars). }\end{array}$ \\
\hline
\end{tabular}




\begin{tabular}{|c|c|c|}
\hline \multicolumn{2}{|c|}{ Frequency of traffic intensity } & Variability of traffic intensity - SV \\
\hline II/602 & $\begin{array}{l}\text { Pelhřimov, Jihlava, } \\
\text { Velké Meziřící, Velká } \\
\text { Bíteš }\end{array}$ & $\begin{array}{l}\text { In the city of Brno a total of } 20503 \text { vehicles ( } 2312 \text { heavy- } \\
\text { duty, } 18066 \text { passenger cars); between Brno and Velká Bíteš } \\
\text { a total of } 3096 \text { vehicles ( } 511 \text { heavy-duty, } 2582 \text { passenger } \\
\text { cars); in the town of Velká Bíteš } 5854 \text { vehicles ( } 1155 \\
\text { heavy-duty, } 4645 \text { passenger cars); crossing with II/390 } \\
\text { total } 3615 \text { vehicles ( } 703 \text { heavy-duty, } 2866 \text { passenger cars); } \\
\text { from crossing with II/390 to Velké Meziříći } 2931 \text { vehicles } \\
\text { ( } 605 \text { heavy-duty, } 2300 \text { passenger cars); } 16401 \text { vehicles } \\
\text { in the town of Velké Meziříći ( } 2197 \text { heavy-duty, } 12305 \\
\text { passenger cars); from Velké Meziříćí to EXIT } 141 \text { in total } \\
12860 \text { vehicles ( } 1734 \text { heavy-duty, } 10954 \text { passenger cars); } \\
\text { from EXIT } 141 \text { to EXIT } 134 \text { in total } 4861 \text { vehicles ( } 1104 \\
\text { heavy-duty; } 3726 \text { passenger cars); from Měřín to cross } \\
\text { with II/351 total } 2911 \text { vehicles ( } 637 \text { heavy-duty, } \\
2255 \text { passenger cars); from the intersection with II/351 after } \\
\text { crossing with II/404 total } 3921 \text { vehicles ( } 635 \text { heavy-duty, } \\
3262 \text { passenger cars); from crossing II/404 to Velký } \\
\text { Beranov total } 5689 \text { (1163 heavy-duty, } 4585 \text { passenger } \\
\text { cars); from Velký Beranov to Jihlava } 11987 \text { vehicles (1376 } \\
\text { heavy-duty, } 10541 \text { passenger cars); Jihlava } 15781 \text { vehicles } \\
\text { (1907 heavy-duty, } 13763 \text { passenger cars); Jihlava after } \\
\text { splitting II/406 total } 13380 \text { vehicles (1841 heavy-duty, } 11466 \\
\text { passenger cars); after splitting with II/406 beyond Pelhřimov } \\
3762 \text { vehicles (685 heavy-duty, } 3054 \text { passenger cars); } \\
\text { Pelhřimov } 6362 \text { vehicles ( } 654 \text { heavy-duty, } 5690 \text { passenger } \\
\text { cars). }\end{array}$ \\
\hline II/130 & $\begin{array}{l}\text { Křelovice, Senožonaty, } \\
\text { Koberovice, Ledeč } \\
\text { nad Sázavou, Golčův } \\
\text { Jeníkov }\end{array}$ & $\begin{array}{l}\text { From Křelovice to EXIT } 81 \text { a total of } 1531 \text { vehicles } \\
\text { ( } 303 \text { heavy-duty, } 1202 \text { passenger cars); from EXIT } 81 \text { to } \\
\text { the combined with II/150 total } 2295 \text { ( } 324 \text { heavy-duty, } \\
1958 \text { passenger cars); in the town of Pelhřimov } 8190 \\
\text { vehicles ( } 864 \text { heavy-duty, } 7283 \text { passenger cars); Pelhřimov } \\
\text { after crossing with III/1308 total } 1674 \text { vehicles ( } 271 \text { heavy- } \\
\text { duty, } 1388 \text { passenger cars); after crossing with III/1308 } \\
\text { outside Leština u Světlé total } 928 \text { vehicles ( } 220 \text { heavy-duty, } \\
698 \text { passenger cars); from Leština to Světlá after crossing } \\
\text { with I/38 total } 606 \text { vehicles ( } 75 \text { heavy-duty, } 524 \text { passenger } \\
\text { cars). }\end{array}$ \\
\hline II/345 & $\begin{array}{l}\text { Golčův Jeníkov, } \\
\text { Chotěboř, }\end{array}$ & $\begin{array}{l}\text { From Ždírec nad Doubravou to Chotěboř a total of } \\
4255 \text { vehicles ( } 758 \text { heavy-duty, } 3481 \text { passenger cars); in } \\
\text { Chotěboř a total of } 5993 \text { vehicles ( } 1218 \text { heavy-duty, } 4756 \\
\text { passenger cars); from Chotěboř to Nová Ves near Chotěboř } \\
\text { total } 3069 \text { vehicles ( } 630 \text { heavy-duty, } 2415 \text { passenger cars); } \\
\text { Chotěboř next to Golčùv Jeníkov total } 2508 \text { vehicles } \\
\text { (512 heavy-duty, } 1970 \text { passenger cars). }\end{array}$ \\
\hline II/344 & $\begin{array}{l}\text { Chotěboř, Dolní Krupá, } \\
\text { Havlíčkưv Brod }\end{array}$ & $\begin{array}{l}\text { From Havlíčkův Brod to Chotěboř a total of } 3256 \text { vehicles } \\
\text { ( } 329 \text { heavy-duty, } 2911 \text { passenger cars); in the town } \\
\text { of Chotěboř a total of } 6240 \text { vehicles ( } 852 \text { heavy-duty, } \\
5330 \text { passenger cars); from Chotěboř to Jeníkovec a total } \\
\text { of } 737 \text { vehicles ( } 93 \text { heavy-duty, } 636 \text { passenger cars); a road } \\
\text { from Jeníkov to Hodonín was not measured. }\end{array}$ \\
\hline
\end{tabular}




\begin{tabular}{|c|c|c|}
\hline \multicolumn{2}{|c|}{ Frequency of traffic intensity } & \multirow[b]{2}{*}{$\begin{array}{l}\text { Variability of traffic intensity - SV } \\
\text { From Havlíčkův Brod to Světlá nad Sázavou } 3427 \text { vehicles } \\
\text { ( } 464 \text { heavy-duty, } 2942 \text { passenger cars); from Světlá nad } \\
\text { Sázavou to Ledeč nad Sázavou } 2923 \text { vehicles } \\
\text { ( } 329 \text { heavy-duty, } 2584 \text { passenger cars); from Ledeč nad } \\
\text { Sázavou to crossing II/336 total } 2488 \text { vehicles ( } 409 \text { heavy- } \\
\text { duty, } 2049 \text { passenger cars); from the crossing with II/336 } \\
\text { after EXIT } 66 \text { total of } 1118 \text { vehicles ( } 199 \text { heavy-duty, } \\
917 \text { passenger cars); from EXIT } 66 \text { to Čechtice } \\
1724 \text { vehicles ( } 441 \text { heavy-duty, } 1281 \text { passenger cars); from } \\
\text { Čechtice to Čáslavsko total of } 974 \text { vehicles ( } 227 \text { heavy-duty, } \\
734 \text { passenger cars); from Čáslavsko to Horní Lhota there } \\
\text { is no section of measurement; from Horní Lhota to Olešná } \\
\text { a total of } 480 \text { vehicles ( } 106 \text { heavy-duty, } \\
372 \text { passenger cars); from Olešná to Louňovice pod } \\
\text { Blaníkem a total of } 494 \text { vehicles ( } 77 \text { heavy-duty, } \\
410 \text { passenger cars); from Louňovice pod Blaníkem to } \\
\text { Votice } 1180 \text { vehicles (183 heavy-duty, } 987 \text { passenger cars). }\end{array}$} \\
\hline II/150 & $\begin{array}{l}\text { Ledeč nad Sázavou, } \\
\text { Světlá nad Sázavou, } \\
\text { Havlíčkův Brod }\end{array}$ & \\
\hline II/347 & $\begin{array}{l}\text { Světlá nad Sázavou, } \\
\text { Humpolec }\end{array}$ & $\begin{array}{l}\text { In the town of Humpolec } 6344 \text { vehicles ( } 875 \text { heavy-duty, } \\
5389 \text { passenger cars); from Humpolec to Světlá nad } \\
\text { Sázavou a total of } 2046 \text { vehicles ( } 300 \text { heavy-duty, } \\
1698 \text { passenger cars); from Světlá nad Sázavou to Habra } \\
1565 \text { vehicles ( } 226 \text { heavy-duty, } 1330 \text { passenger cars). }\end{array}$ \\
\hline $11 / 405$ & Jihlava, Třebíč & $\begin{array}{l}\text { From Jihlava to Brtnice a total of } 6160 \text { vehicles ( } 788 \text { heavy- } \\
\text { duty, } 5332 \text { passenger cars); from Brtnice to connection } \\
\text { with II/402 a total of } 3111 \text { vehicles ( } 448 \text { heavy-duty, } \\
2630 \text { passenger cars); from connection II/402 to Okřišsy } \\
\text { a total of } 4346 \text { vehicles ( } 497 \text { heavy-duty, } 3826 \text { passenger } \\
\text { cars); from Okříšky to connection with I/23 total of } 4963 \\
\text { vehicles ( } 680 \text { heavy-duty, } 4243 \text { passenger cars). }\end{array}$ \\
\hline $11 / 360$ & $\begin{array}{l}\text { Moravec, Křižanov, } \\
\text { Velké Meziříčí, Třebíč, } \\
\text { Jaroměřice nad } \\
\text { Rokytnou }\end{array}$ & $\begin{array}{l}\text { From Jaroměřice nad Rokytnou to Výčapy a total } \\
\text { of } 5089 \text { vehicles ( } 709 \text { heavy-duty, } 4361 \text { passenger cars); } \\
\text { from Výčapy to Třebíč } 6369 \text { vehicles in total ( } 865 \text { heavy- } \\
\text { duty, } 5502 \text { passenger cars); in the town Třebíč } 8364 \\
\text { vehicles in total ( } 1061 \text { heavy-duty, } 7248 \text { passenger cars); } \\
\text { from Třebíč to crossing with II/390 total of } 6666 \text { vehicles } \\
\text { ( } 869 \text { heavy-duty, } 5627 \text { passenger cars); from the crossing } \\
\text { with II/390 outside Velké Meziříči } 4445 \text { vehicles } \\
\text { ( } 837 \text { heavy-duty, } 3575 \text { passenger cars); in Velké Meziříćí } \\
5495 \text { vehicles in total ( } 804 \text { heavy-duty, } 4652 \text { passenger } \\
\text { cars); from Velké Meziř́ičí to Křižanov total of } 2623 \text { vehicles } \\
\text { ( } 407 \text { heavy-duty, } 2193 \text { passenger cars); from Křižanov to } \\
\text { Moravec a total of } 2811 \text { vehicles ( } 445 \text { heavy-duty, } \\
2340 \text { passenger cars); from Moravec to Bobrová a total } \\
\text { of } 2417 \text { vehicles ( } 339 \text { heavy-duty, } 2063 \text { passenger cars); } \\
\text { from Bobrová to Nové Město na Moravě a total } \\
\text { of } 2552 \text { vehicles ( } 336 \text { heavy-duty, } 2184 \text { passenger cars); } \\
\text { from Nové Město na Moravě to Jimramov a total of } 1863 \\
\text { vehicles ( } 352 \text { heavy-duty, } 1481 \text { passenger cars); from } \\
\text { Jimramov to the border of region a total of } 2031 \text { vehicles } \\
\text { ( } 381 \text { heavy-duty, } 1629 \text { passenger cars). }\end{array}$ \\
\hline
\end{tabular}




\begin{tabular}{|c|c|c|}
\hline \multicolumn{2}{|c|}{ Frequency of traffic intensity } & Variability of traffic intensity - SV \\
\hline II/360 & $\begin{array}{l}\text { Nové Město na Moravě, } \\
\text { Jimramov, regional } \\
\text { border }\end{array}$ & $\begin{array}{l}\text { From Jaroměřice nad Rokytnou to Výčapy a total } \\
\text { of } 5089 \text { vehicles ( } 709 \text { heavy-duty, } 4361 \text { passenger cars); } \\
\text { from Výčapy to Třebíč } 6369 \text { vehicles in total ( } 865 \text { heavy- } \\
\text { duty, } 5502 \text { passenger cars); in the town Třebíč } 8364 \\
\text { vehicles in total ( } 1061 \text { heavy-duty, } 7248 \text { passenger cars); } \\
\text { from Třebíč to crossing with II/390 total of } 6666 \text { vehicles } \\
\text { ( } 869 \text { heavy-duty, } 5627 \text { passenger cars); from the crossing } \\
\text { with II/390 to Velké Meziříči } 4445 \text { vehicles ( } 837 \text { heavy-duty, } \\
3575 \text { passenger cars); in Velké Meziříčí } 5495 \text { vehicles } \\
\text { ( } 804 \text { heavy-duty, } 4652 \text { passenger cars); from Velké Meziříćí } \\
\text { to Křižanov total } 2623 \text { vehicles ( } 407 \text { heavy-duty, } 2193 \\
\text { passenger cars); from Křižanov to Moravec a total } \\
\text { of } 2811 \text { vehicles ( } 445 \text { heavy-duty, } 2340 \text { passenger cars); } \\
\text { from Moravec to Bobrová a total of } 2417 \text { vehicles } \\
\text { (339 heavy-duty, } 2063 \text { passenger cars); from Bobrová to } \\
\text { Nové Město na Moravě a total of } 2552 \text { vehicles (336 heavy- } \\
\text { duty, } 2184 \text { passenger cars); from Nové Město na Moravě to } \\
\text { Jimramov a total of } 1863 \text { vehicles ( } 352 \text { heavy-duty, } \\
1481 \text { passenger cars); from Jimramov to the regional border } \\
\text { a total of } 2031 \text { vehicles ( } 381 \text { heavy-duty, } 1629 \text { passenger } \\
\text { cars). }\end{array}$ \\
\hline II/152 & $\begin{array}{l}\text { Jaroměřice nad } \\
\text { Rokytnou, Moravské } \\
\text { Budějovice, Jemnice }\end{array}$ & $\begin{array}{l}\text { In the city of Nová Bystřice a total of } 2535 \text { vehicles } \\
\text { ( } 257 \text { heavy-duty, } 2228 \text { passenger cars); from Nová Bystřice } \\
\text { to Slavonice } 1005 \text { vehicles ( } 134 \text { heavy-duty, } 865 \text { passenger } \\
\text { cars); in the town Slavonice } 2387 \text { vehicles ( } 315 \text { heavy-duty, } \\
2052 \text { passenger cars); from Slavonice to Staré Hobží a total } \\
\text { of } 859 \text { vehicles ( } 150 \text { heavy-duty, } 695 \text { passenger cars); from } \\
\text { Staré Hobží to Jemnice } 1405 \text { vehicles ( } 157 \text { heavy-duty, } \\
1229 \text { passenger cars); in a town Jemnice } 5606 \text { vehicles } \\
\text { ( } 635 \text { heavy-duty, } 4894 \text { passenger cars); from Jemnice to } \\
\text { Moravské Budějovice a total of } 2805 \text { vehicles } \\
\text { ( } 465 \text { heavy-duty, } 2306 \text { passenger cars); in the city } \\
\text { of Moravské Budějovice a total of } 7146 \text { vehicles } \\
\text { ( } 624 \text { heavy-duty, } 6477 \text { passenger cars); from Moravské } \\
\text { Budějovice to Jaroměřice nad Rokytnou } 4880 \text { vehicles in } \\
\text { total (680 heavy-duty, } 4188 \text { passenger cars); in the city } \\
\text { of Jaromerřice nad Rokytnou a total of } 3809 \text { vehicles } \\
\text { ( } 554 \text { heavy-duty, } 3221 \text { passenger cars); from Jaroměřice } \\
\text { nad Rokytnou to the crossing with II/399 a total } \\
\text { of } 2362 \text { vehicles ( } 403 \text { heavy-duty, } 1931 \text { passenger cars); } \\
\text { from the crossing with II/399 to Slavětice a total } \\
\text { of } 4068 \text { vehicles ( } 760 \text { heavy-duty, } 3262 \text { passenger cars); } \\
\text { from Slavětice to Dukovany total of } 3218 \text { vehicles } \\
\text { ( } 567 \text { heavy-duty, } 2628 \text { passenger cars). }\end{array}$ \\
\hline II/408 & $\begin{array}{l}\text { Jemnice - regional } \\
\text { border }\end{array}$ & $\begin{array}{l}\text { From Jemnice to the border of the region } 2494 \text { vehicles in } \\
\text { total ( } 392 \text { heavy-duty, } 2064 \text { passenger cars). }\end{array}$ \\
\hline
\end{tabular}




\begin{tabular}{|c|c|c|}
\hline \multicolumn{2}{|c|}{ Frequency of traffic intensity } & \multirow[b]{2}{*}{$\begin{array}{l}\text { Variability of traffic intensity - SV } \\
\text { From Jemnice to Želetava a total of } 880 \text { vehicles ( } 130 \\
\text { heavy-duty, } 740 \text { passenger cars); in the city of Želetava } 1205 \\
\text { vehicles in total ( } 96 \text { heavy-duty, } 1106 \text { passenger cars); from } \\
\text { Želetava to Rokytnice nad Rokytnou a total of } 429 \text { vehicles } \\
\text { ( } 58 \text { heavy-duty, } 369 \text { passenger cars); from Rokytnice nad } \\
\text { Rokytnou to Stařeč total of } 686 \text { vehicles ( } 107 \text { heavy-duty, } \\
555 \text { passenger cars); from Stařeč to Třebíč a total of } 4700 \\
\text { vehicles ( } 440 \text { heavy-duty, } 4170 \text { passenger cars). }\end{array}$} \\
\hline II/410 & $\begin{array}{l}\text { Jemnice - regional } \\
\text { border }\end{array}$ & \\
\hline II/152 & $\begin{array}{l}\text { Jaroměřice nad } \\
\text { Rokytnou, Hrotovice, } \\
\text { regional border }\end{array}$ & $\begin{array}{l}\text { From the border of the region to Slavoň a total of } 1005 \\
\text { vehicles ( } 134 \text { heavy-duty, } 865 \text { passenger cars); from } \\
\text { Slavoň to Staré Hobzí } 859 \text { vehicles ( } 150 \text { heavy-duty, } \\
695 \text { passenger cars); from Staré Hobzí to Jemnice } 1209 \\
\text { vehicles ( } 192 \text { heavy-duty, } 998 \text { passenger cars), in a town } \\
\text { Jemnice a total of } 5606 \text { vehicles ( } 635 \text { heavy-duty, } 4894 \\
\text { passenger cars); from Jemnice to Moravské Budějovice } \\
\text { a total of } 2805 \text { vehicles ( } 465 \text { heavy-duty, } 2306 \text { passenger } \\
\text { cars); in the city of Moravské Budějovice } 7146 \text { vehicles } \\
\text { (624 heavy-duty, } 6477 \text { passenger cars); from Moravské } \\
\text { Budějovice to Jaroměřice nad Rokytnou } 4880 \text { ( } 680 \text { heavy- } \\
\text { duty, } 4188 \text { passenger cars); from Jaroměřice nad Rokytnou } \\
\text { to Hrotovice a total of } 2362 \text { vehicles ( } 403 \text { heavy-duty, } 1931 \\
\text { passenger cars); from Hrotovice to Slavětice a total of } 4068 \\
\text { vehicles ( } 760 \text { heavy-duty, } 3262 \text { passenger cars); from } \\
\text { Slavětice to Dukovany } 4089 \text { vehicles ( } 916 \text { heavy-duty, } \\
3166 \text { passenger cars). }\end{array}$ \\
\hline II/399 & $\begin{array}{l}\text { Třešovice, Dalešice, } \\
\text { Rouchovany, regional } \\
\text { border }\end{array}$ & $\begin{array}{l}\text { From the border of the region to Rouchovany a total } \\
\text { of } 560 \text { vehicles ( } 86 \text { heavy-duty, } 471 \text { passenger cars); from } \\
\text { Rouchovany to the crossing with II/152 } 1532 \text { vehicles in total } \\
\text { ( } 266 \text { heavy-duty, } 1243 \text { passenger cars); from the crossing } \\
\text { with II/152 to Dalešice a total of } 2320 \text { vehicles ( } 390 \text { heavy- } \\
\text { duty, } 1877 \text { passenger cars); from Dalešice to Třešovice } \\
\text { a total of } 594 \text { vehicles ( } 101 \text { heavy-duty, } 490 \text { passenger } \\
\text { cars); from Třešovice to the I/23 a total of } 1091 \text { vehicles } \\
\text { (129 heavy-duty, } 957 \text { passenger cars); from Náměšt' nad } \\
\text { Oslavou to EXIT } 162 \text { a total of } 2584 \text { vehicles ( } 463 \text { heavy- } \\
\text { duty, } 2110 \text { passenger cars). }\end{array}$ \\
\hline $11 / 399$ & $\begin{array}{l}\text { Náměšt' nad Oslavou, } \\
\text { Jinošov, Velká Bíteš }\end{array}$ & $\begin{array}{l}\text { From the border of the region to Rouchovany a total } \\
\text { of } 560 \text { vehicles ( } 86 \text { heavy-duty, } 471 \text { passenger cars); from } \\
\text { Rouchovany to the crossing with II/152 } 1532 \text { vehicles in total } \\
\text { ( } 266 \text { heavy-duty, } 1243 \text { passenger cars); from the crossing } \\
\text { with II/152 to Dalešice a total of } 2320 \text { vehicles ( } 390 \text { heavy- } \\
\text { duty, } 1877 \text { passenger cars); from Dalešice to Třešovice } \\
\text { a total of } 594 \text { vehicles (101 heavy-duty, } 490 \text { passenger } \\
\text { cars); from Třešovice to crossroad with I/23 a total of } 1091 \\
\text { vehicles ( } 129 \text { heavy-duty, } 957 \text { passenger cars); from } \\
\text { Náměšt' nad Oslavou to EXIT } 162 \text { a total of } 2584 \text { vehicles } \\
\text { ( } 463 \text { heavy-duty, } 2110 \text { passenger cars). }\end{array}$ \\
\hline II/379 & $\begin{array}{l}\text { Velká Bíteš - regional } \\
\text { border }\end{array}$ & $\begin{array}{l}\text { From Velká Bíteš to the border of the region } 2890 \text { vehicles } \\
\text { ( } 550 \text { heavy-duty, } 2312 \text { passenger cars). }\end{array}$ \\
\hline
\end{tabular}




\begin{tabular}{|c|c|c|}
\hline \multicolumn{2}{|c|}{ Frequency of traffic intensity } & \multirow{2}{*}{$\begin{array}{l}\text { Variability of traffic intensity - SV } \\
\text { In the city of Bystřice nad Pernštejnem a total of } \\
3241 \text { vehicles ( } 198 \text { heavy-duty, } 3008 \text { passenger cars); from } \\
\text { Bystřice nad Pernštejnem to Dalečín } 1741 \text { vehicles in total } \\
\text { (176 heavy-duty, } 1554 \text { passenger cars); from Dalečín to } \\
\text { Jimramov a total of } 816 \text { vehicles (158 heavy-duty, } \\
640 \text { passenger cars). }\end{array}$} \\
\hline $11 / 357$ & $\begin{array}{l}\text { Bystřice nad } \\
\text { Pernštejnem, Dalečín, } \\
\text { Jimramov }\end{array}$ & \\
\hline II/387 & $\begin{array}{l}\text { Štěpánov nad Svratkou, } \\
\text { regional border }\end{array}$ & $\begin{array}{l}\text { From Vír to Štěpánov nad Svratkou a total of } 562 \text { vehicles } \\
\text { ( } 90 \text { heavy-duty, } 470 \text { passenger cars); from Štěpánov nad } \\
\text { Svratkou to Nedvědice a total of } 2621 \text { vehicles } \\
\text { ( } 299 \text { heavy-duty, } 2304 \text { passenger cars). }\end{array}$ \\
\hline $11 / 345$ & $\begin{array}{l}\text { Chotěboř, Ždírec nad } \\
\text { Doubravou }\end{array}$ & $\begin{array}{l}\text { From Golčův Jeníkov to Nová Ves u Chotěboře } \\
2513 \text { vehicles in total ( } 456 \text { heavy-duty, } 2045 \text { passenger } \\
\text { cars); from Nová Ves u Chotěboře to Chotěboř a total } \\
\text { of } 3069 \text { vehicles ( } 630 \text { heavy-duty, } 2415 \text { passenger cars); in } \\
\text { the city of Chotěboř } 5993 \text { vehicles ( } 1218 \text { heavy-duty, } \\
4756 \text { passenger cars); from Chotěboř to Ždírec nad } \\
\text { Doubravou a total of } 4255 \text { vehicles ( } 758 \text { heavy-duty, } \\
3481 \text { passenger cars). }\end{array}$ \\
\hline $11 / 352$ & Jihlava, Polná & $\begin{array}{l}\text { From the disconnection from } 1 / 38 \text { to Polná a total of } \\
1753 \text { vehicles ( } 298 \text { heavy-duty, } 1441 \text { passenger cars); from } \\
\text { Polná to the connection to } 1 / 19 \text { a total of } 480 \text { vehicles } \\
\text { ( } 73 \text { heavy-duty, } 403 \text { passenger cars). }\end{array}$ \\
\hline II/351 & $\begin{array}{l}\text { Polná, Pribyslav - end } \\
\text { of road with this number }\end{array}$ & $\begin{array}{l}\text { From Přibyslav to Polná a total of } 1336 \text { vehicles } \\
\text { ( } 213 \text { heavy-duty, } 1098 \text { passenger cars); from Polná to } \\
\text { the crossing with II/353 a total of } 1336 \text { vehicles } \\
\text { ( } 213 \text { heavy-duty, } 1098 \text { passenger cars); from the crossing } \\
\text { with II/353 to the crossing with II/602 a total of } 551 \text { vehicles } \\
\text { ( } 104 \text { heavy-duty, } 435 \text { passenger cars); from the crossing } \\
\text { with III/602 to Čechtín a total of } 1695 \text { vehicles } \\
\text { ( } 226 \text { heavy-duty, } 1453 \text { passenger cars); from Čechtín to } \\
\text { Třebíč a total of } 1053 \text { vehicles ( } 113 \text { heavy-duty, } \\
32 \text { passenger cars); in the city of Třebíč } 13561 \text { vehicles in } \\
\text { total ( } 2217 \text { heavy-duty, } 11201 \text { passenger cars); from Třebíc } \\
\text { to the crossing with II/401 a total of } 5064 \text { vehicles } \\
\text { (689 heavy-duty, } 4345 \text { passenger cars); from } \\
\text { the intersection with II/401 to the connection with } \\
\text { II/399 } 4010 \text { vehicles in total ( } 576 \text { heavy-duty, } \\
3393 \text { passenger cars). }\end{array}$ \\
\hline III/3507 & $\begin{array}{l}\text { Přibyslav, Havlíčková } \\
\text { Borová, Ždírec nad } \\
\text { Doubravou }\end{array}$ & $\begin{array}{l}\text { From the crossroad with II/350 to Havlíčková Borová a total } \\
\text { of } 1072 \text { vehicles ( } 232 \text { heavy-duty, } 833 \text { passenger cars); in } \\
\text { Havlíčková Borová a total of } 1681 \text { vehicles } \\
\text { ( } 318 \text { heavy-duty, } 1343 \text { passenger cars); from Havlíčková } \\
\text { Borová to the connection with } 1 / 34 \text { a total of } 884 \text { vehicles } \\
\text { (158 heavy-duty, } 723 \text { passenger cars). }\end{array}$ \\
\hline
\end{tabular}

Source: (Černý, 2015) 
Table 5 | Intensity of TV heavy vehicles

\begin{tabular}{|c|c|c|}
\hline \multicolumn{2}{|r|}{ Major settlements on the backbone road network } & \multirow{2}{*}{$\begin{array}{l}\text { Variability of traffic intensity - TV } \\
\text { Add from Černovice } 212,218, \text { behind } \\
\text { Pacov } 380,264\end{array}$} \\
\hline II/128 & Černovice, Pacov, Salačova Lhota, Lukavec & \\
\hline $11 / 409$ & $\begin{array}{l}\text { Černovice, Kamenice nad Lipou, Žirovnice, } \\
\text { Počátky }\end{array}$ & From Černovice 141, 232, 157, 172 \\
\hline II/132 & Počátky, Horní Cerekev & 249 \\
\hline II/112 & $\begin{array}{l}\text { Telč, Horní Cerekev, Pelhřimov, Červená Řečice, } \\
\text { Košetice }\end{array}$ & From Telč 144, 113, 278, 367, 360, 177 \\
\hline II/406 & Regional border, Telč, Třešt', Kostelec & $\begin{array}{l}\text { From the border of the region } 385,587 \text {, } \\
697,680\end{array}$ \\
\hline II/602 & Pelhřimov, Jihlava, Velké Meziříčí, Velká Bíteš & $\begin{array}{l}\text { From Pelhřimov 594, 602, 714, before } \\
\text { Jihlava 1925, 1158, beyond Jihlava } 1325\end{array}$ \\
\hline II/130 & $\begin{array}{l}\text { Křelovice, Senožonaty, Koberovice, Ledeč nad } \\
\text { Sázavou, Golčův Jeníkov }\end{array}$ & From Křelovice 138, 185 \\
\hline $11 / 345$ & Golčův Jeníkov, Chotěboř & From Golčův Jeníkov 474, 527 \\
\hline II/344 & Chotěboř, Dolní Krupá, Havličkův Brod & From Chotěboř 474,527 \\
\hline II/150 & $\begin{array}{l}\text { Ledeč nad Sázavou, Světlá nad Sázavou, } \\
\text { Havličč̉v Brod }\end{array}$ & From Ledeč 357, 549 \\
\hline II/347 & Světlá nad Sázavou, Humpolec & From Světlá nad Sázavou 145, 175 \\
\hline II/405 & Jihlava, Třebíč & $\begin{array}{l}\text { From Jihlava } 725,474,244,227,314, \\
349\end{array}$ \\
\hline $11 / 360$ & $\begin{array}{l}\text { Moravec, Křižanov, Velké Meziříčí, Třebíč, Ja- } \\
\text { roměřice nad Rokytnou }\end{array}$ & From Moravec 195, 615, 817, 562 \\
\hline II/360 & $\begin{array}{l}\text { Nové Město na Moravě, Jimramov, regional } \\
\text { border }\end{array}$ & From Nové Město 478, 219, 169 \\
\hline II/152 & $\begin{array}{l}\text { Jaroměřice nad Rokytnou, Moravské Budějovi- } \\
\text { ce, Jemnice }\end{array}$ & From Jaroměřice 689, 318, 284, 104 \\
\hline $11 / 408$ & Jemnice - regional border & From Jemnice 127 \\
\hline II/410 & Jemnice - regional border & From Jemnice 42 \\
\hline II/152 & $\begin{array}{l}\text { Jaroměřice nad Rokytnou, Hrotovice, regional } \\
\text { border }\end{array}$ & From Jaroměřice 255, 367, 252 \\
\hline II/399 & Třesov, Dalešice, Rouchovany, regional border & From Třesov 63, 357, 262, 85 \\
\hline 11/399 & Náměšt' nad Oslavou, Jinošov, Velká Bíteš & From Náměšt' nad Oslavou 580 \\
\hline $11 / 379$ & Velká Bíteš - regional border & From Velká Bíteš 621, 359 \\
\hline $11 / 357$ & Bystřice nad Pernštejnem, Dalečín, Jimramov & From Bystřice 152, 143, 126 \\
\hline $11 / 387$ & Štěpánov nad Svratkou, regional border & From Štěpánov 224 \\
\hline $11 / 345$ & Chotěboř, Ždírec nad Doubravou & From Chotěboř 974,605 \\
\hline $11 / 352$ & Jihlava, Polná & From Jihlava 136 \\
\hline $11 / 351$ & Polná, Přibyslav & From Polná 189 \\
\hline
\end{tabular}

Source: (Černý, 2015) 
In order to evaluate the significance of the communication, we can compare the intensity of traffic (individual types) with the number of inhabitants living in selected major settlements on the relevant roads. From the point of view of determining the ratios, this has a considerable limitation because it is not possible to determine the relative indicators related to the average values since not all the seats on the given road are counted and the indicator of the traffic intensity is a variable indicator, for example, the connection of other roads to the relevant road communication. For this reason, two ratios were selected that measure the significance of the communication to the selected residential structure on the relevant communication. In terms of traffic variability, it is necessary to evaluate the indicator as a whole for the relevant communication. Another significant indicator is the TV/SV indicator, which represents the percentage load of heavy vehicles and thus the economic importance of the road.

The ratios are expressed as follows

$$
\begin{gathered}
U_{\min }=\frac{\text { The highest intensity }}{\text { The highest number of people }} * 100 ; \\
U_{\text {max }}=\frac{\text { The highest intensity }}{\text { The lowest number of people }} * 100 ; \\
U_{k}=\frac{\mathrm{TV} \mathrm{U}(\mathrm{min})}{\mathrm{SV} \mathrm{U}(\mathrm{min})} * 100 .
\end{gathered}
$$

\section{Results}

From the Table 6 , it can be predicted that the lower the variance of the $U_{\max }$ and $U_{\min }$, indicators, the more uniform stratification of the settlement structure on the given road. Furthermore, the higher the value of the $U_{\text {min }}$ indicator, the more important the road is in terms of social and economic importance. The $U_{k}$ ratio is the percentage of heavy vehicle weight. In general, it can be said that the higher the percentage, the higher the economic importance of the road. 
Table 6 | Significance of communication (\%)

\begin{tabular}{|c|c|c|c|c|c|}
\hline \multicolumn{6}{|c|}{ Significance of communication (\%) } \\
\hline \multirow[b]{2}{*}{ Road number } & \multicolumn{2}{|c|}{ SV Indicator } & \multicolumn{2}{|c|}{ TV Indicator } & \multirow[b]{2}{*}{$U_{k}$ Ratio } \\
\hline & $U(\min )$ & $U(\max )$ & $U$ (min) & $U(\max )$ & \\
\hline II/128 & 36.6 & 1363.6 & 7.7 & 287.8 & 21.04 \\
\hline $11 / 409$ & 41.8 & 91.4 & 6.0 & 13.0 & 14.35 \\
\hline II/132 & 44.0 & 64.8 & 9.3 & 13.7 & 21.14 \\
\hline II/112 & 181.9 & 203.9 & 2.3 & 39.0 & 1.26 \\
\hline $11 / 406$ & 73.6 & 476.9 & 12.1 & 11.8 & 16.44 \\
\hline II/602 & 24.1 & 239.2 & 3.8 & 38.2 & 15.77 \\
\hline II/130 & 55.3 & 413.1 & 3.4 & 125.9 & 6.15 \\
\hline $11 / 345$ & 33.0 & 118.0 & 5.6 & 20.1 & 16.97 \\
\hline $11 / 344$ & 13.8 & 789.9 & 2.2 & 127.0 & 15.94 \\
\hline II/150 & 17.6 & 77.8 & 2.3 & 10.2 & 13.07 \\
\hline $11 / 347$ & 14.5 & 22.6 & 1.6 & 2.5 & 11.03 \\
\hline $11 / 405$ & 10.0 & 13.6 & 1.4 & 2.0 & 14.00 \\
\hline $11 / 360$ & 19.0 & 1168.0 & 2.2 & 135.7 & 11.58 \\
\hline $11 / 360$ & 26.5 & 226.6 & 4.8 & 40.9 & 18.11 \\
\hline II/152 & 60.1 & 109.3 & 9.1 & 16.6 & 15.14 \\
\hline $11 / 408$ & 42.8 & 42.8 & 3.0 & 3.0 & 7.01 \\
\hline $1 / / 410$ & 24.0 & 24.0 & 1.0 & 1.0 & 4.17 \\
\hline II/152 & 62.2 & 263.5 & 16.6 & 40.1 & 26.69 \\
\hline II/399 & 202.9 & 2473.4 & 31.2 & 379.8 & 15.38 \\
\hline II/399 & 74.3 & 1554.8 & 11.5 & 240.7 & 15.48 \\
\hline II/379 & 64.6 & 64.6 & 12.3 & 12.3 & 19.04 \\
\hline II/357 & 34.3 & 450.6 & 1.8 & 24.1 & 5.25 \\
\hline $11 / 387$ & 223.4 & 223.4 & 32.6 & 35.6 & 14.59 \\
\hline $11 / 345$ & 55.8 & 168.4 & 10.4 & 31.5 & 18.64 \\
\hline $11 / 352$ & 2.9 & 28.7 & 0.3 & 2.7 & 10.34 \\
\hline II/351 & 19.4 & 25.6 & 3.7 & 4.9 & 19.07 \\
\hline
\end{tabular}

Source: (Černý, 2015) 
Table 7 | Terrestrial roads arranged according to Indicator $U$ (min)

\begin{tabular}{|c|c|c|c|c|c|}
\hline \multicolumn{3}{|l|}{ SV Ratio } & \multicolumn{2}{|l|}{ TV Ratio } & \multirow{2}{*}{$\begin{array}{l}T V / S V \text { indicator } \\
\text { is calculated } \\
\text { from the value } \\
U \text { (min) }\end{array}$} \\
\hline Road number & $U(\min )$ & $U(\max )$ & $U$ (min) & $U(\max )$ & \\
\hline II/387 & 223.4 & 223.4 & 32.6 & 35.6 & $14.59 \%$ \\
\hline II/399 & 202.9 & 2473.4 & 31.2 & 379.8 & $15.38 \%$ \\
\hline II/112 & 181.9 & 203.9 & 2.3 & 39 & $1.26 \%$ \\
\hline II/399 & 74.3 & 1554.8 & 11.5 & 240.7 & $15.48 \%$ \\
\hline $11 / 406$ & 73.6 & 476.9 & 12.1 & 11.8 & $16.44 \%$ \\
\hline II/379 & 64.6 & 64.6 & 12.3 & 12.3 & $19.04 \%$ \\
\hline II/152 & 62.2 & 263.5 & 16.6 & 40.1 & $26.69 \%$ \\
\hline II/152 & 60.1 & 109.3 & 9.1 & 16.6 & $15.14 \%$ \\
\hline II/345 & 55.8 & 168.4 & 10.4 & 31.5 & $18.64 \%$ \\
\hline II/130 & 55.3 & 413.1 & 3.4 & 125.9 & $6.15 \%$ \\
\hline II/132 & 44 & 64.8 & 9.3 & 13.7 & $21.14 \%$ \\
\hline $11 / 408$ & 42.8 & 42.8 & 3 & 3 & $7.01 \%$ \\
\hline II/409 & 41.8 & 91.4 & 6 & 13 & $14.35 \%$ \\
\hline II/128 & 36.6 & 1363.6 & 7.7 & 287.8 & $21.04 \%$ \\
\hline II/357 & 34.3 & 450.6 & 1.8 & 24.1 & $5.25 \%$ \\
\hline II/345 & 33 & 118 & 5.6 & 20.1 & $16.97 \%$ \\
\hline II/360 & 26.5 & 226.6 & 4.8 & 40.9 & $18.11 \%$ \\
\hline II/602 & 24.1 & 239.2 & 3.8 & 38.2 & $15.77 \%$ \\
\hline II/410 & 24 & 24 & 1 & 1 & $4.17 \%$ \\
\hline \multicolumn{3}{|l|}{ SV Indicator } & \multicolumn{2}{|c|}{ TV Indicator } & $\begin{array}{l}\text { TV/SV Indicator } \\
\text { is calculated }\end{array}$ \\
\hline Road number & $U$ (min) & $U(\max )$ & $U(\min )$ & $U(\max )$ & $\begin{array}{l}\text { from the value } \\
U \text { (min) }\end{array}$ \\
\hline II/351 & 19.4 & 25.6 & 3.7 & 4.9 & $19.07 \%$ \\
\hline II/360 & 19 & 1168 & 2.2 & 135.7 & $11.58 \%$ \\
\hline II/150 & 17.6 & 77.8 & 2.3 & 10.2 & $13.07 \%$ \\
\hline II/347 & 14.5 & 22.6 & 1.6 & 2.5 & $11.03 \%$ \\
\hline II/344 & 13.8 & 789.9 & 2.2 & 127 & $15.94 \%$ \\
\hline II/405 & 10 & 13.6 & 1.4 & 2 & $14.00 \%$ \\
\hline II/352 & 2.9 & 28.7 & 0.3 & 2.7 & $10.34 \%$ \\
\hline III/3507 & & & & & \\
\hline
\end{tabular}

Source: (Černý, 2015) 
Terrestrial roads were analysed on the basis of SV, TV, and TNV. The values of $\mathrm{SV}>1500, \mathrm{TV}>200$ and TNV $>100$ were set to determine the extent of the road network where the road management system could be introduced. Based on these values, a new layout of the backbone network of the Vysočina Region was established. In addition, the roads were analysed as to whether they are of economic significance (i.e. they are only used by freight transport or are of a social nature, i.e. they are predominantly used by passenger cars). These indicators are important in terms of technological procedures. The table below shows the revision of the existing backbone network and the proposal for the exclusion and inclusion of new sections.

Figure 1 | New arrangement of the backbone road network of the Vysočina Region

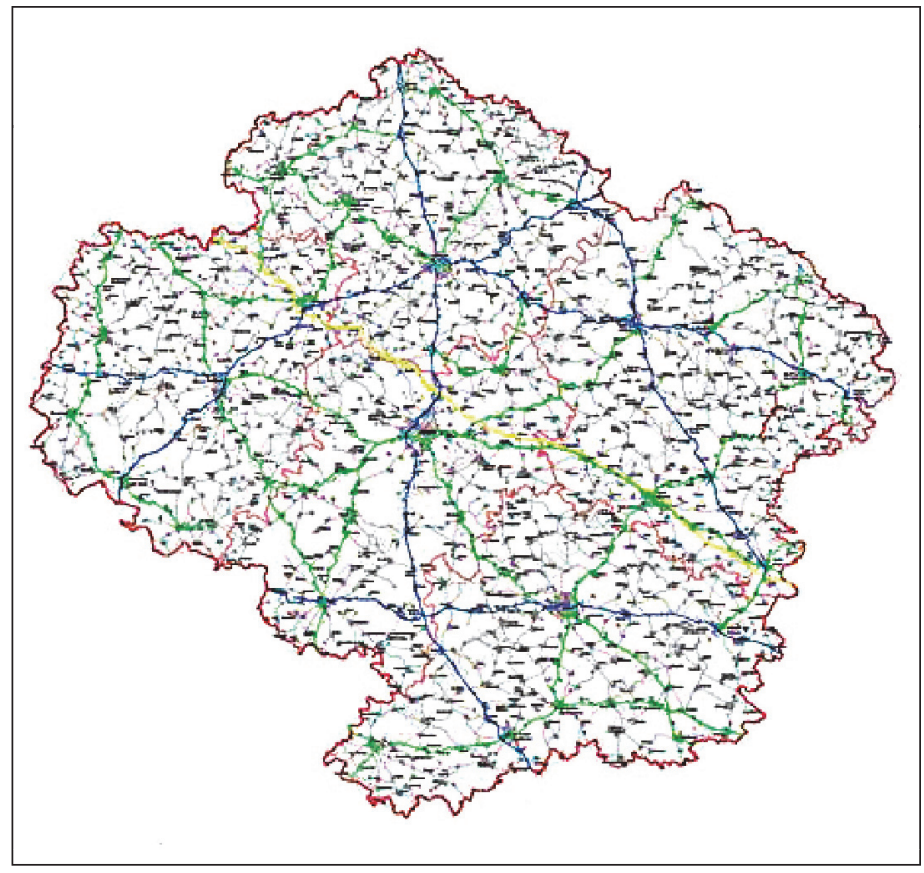

\begin{tabular}{|c|c|c|c|c|}
\hline \multicolumn{5}{|l|}{ Legend: } \\
\hline$\sim$ & Highway & & 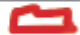 & Regional border \\
\hline 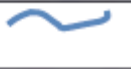 & I. & $\begin{array}{l}\text { Clas } \\
\text { road }\end{array}$ & $\square$ & District border \\
\hline$\frown$ & II. & $\begin{array}{l}\text { Clas } \\
\text { Road }\end{array}$ & $\square$ & Built-up area \\
\hline ح & III. & $\begin{array}{l}\text { Clas } \\
\text { road }\end{array}$ & & \\
\hline$\sim$ & $\begin{array}{l}\text { Does not partic } \\
\text { backbone netw }\end{array}$ & in the & & \\
\hline
\end{tabular}

Source: (Ksusv.cz, 2015) 
Figure 1 shows the network with a total length of $703,107 \mathrm{~km}$, of which $635,84 \mathrm{~km}$ are II. Class roads and the remainder are III. Class roads.

The system for implementing individual repairs and forms of road maintenance is not the subject of this article. To address the issue, based on the basic division of winter maintenance, then full maintenance in a chemical form needs to be discussed. In this case, the roads are cleaned of snow and the surface is treated with chemical spraying. This form of maintenance is the most costly. The second version is the displacement of inert material in order to provide better adhesion conditions when the tyre of a vehicle passes over the road. This procedure is applied especially in areas with low traffic intensity or where chemical substances cannot be used due to nature and landscape conservation. From the viewpoint of spending on winter maintenance, the best way is to simply ploughthe roads without any sprinkling. This method is especially used for third class roads with low traffic intensity and little importance from an economic or social point of view.

\section{The Impact of the Road Network on Public Transport}

The above information can be regarded as general when it affects the operation of transport as a whole system. Although in recent decades there has been a growing importance and intensity of individual automobile transport, as evidenced by data from the above summation, traffic intensity and public support cannot be ignored. In the case of the Vysočina Region, for the most part, it is a public transport service (hereinafter referred to as ZDO), which is mostly ordered by the region. Of course, the highway network of the highlands also uses many other lines, especially long-distance and international ones, but it usually only concerns road 1 . Therefore, these lines will not be dealt with in this article. The largest share consists of suburban and intercity lines, which provide transport for citizens to school, healthcare facilities, and work. Of course, this includes the provision of return transport as stated by current Czech legislation. This service is primarily based on lower class roads and, therefore, the quality of the infrastructure, the arrangement, and maintenance of the infrastructure is of great importance. Particularly in the case of winter maintenance, its plans are adapted in many cases to the times of regular bus services.

This public transport procedure has lasted two decades and has undergone many changes, which reflect the structural changes in the economy, changes in the demographic structure of the region, as well as the mass development of individual traffic. Infrastructure is often a limiting factor shortening driving times as one of the competitive factors of this mode of transport. Other factors include, for example, comfort and cost, which are also affected by the infrastructure. Therefore, it is desirable to coordinate the planning of transport routes, maintenance, building, and changes with regard to public transport as an alternative promoted to the individual. The issue of transport service provision is very broad, and therefore its assessment did not proceed from a purely economic point of view but also from the perspective of sustainable development and social responsibility. It is important to take steps that will help increase traffic efficiency and stop the falling number of passengers. In particular, this is the continuous improvement of the condition of the infrastructure so that it is technically possible to shorten driving times and maintain transfer connections. Quality infrastructure also helps reduce fuel consumption and thereby increases the economic efficiency of the whole system. 


\section{Conclusions}

The contribution is based on a multi-criteria evaluation and introduces a new arrangement of the backbone road network of the Vysočina Region. The highlands region is very specific in many respects, whether in terms of its weather, landscape or socio-demographic. All these aspects are also reflected in the organisation of the road network. Ground communications in the new backbone network layout must be evaluated in terms of their significance and whether they are more of a social or economic significance. The backbone network is made up of the motorway and first class roads that are managed by the MD of the Czech Republic and are connected to these roads by other second and third class roads. Quality and safety are often referred to in terms of transport infrastructure by concepts that, from the owner's point of view, also add value to efficiency and effectiveness. As part of this article, a selection of roadways has been identified on which it is appropriate to introduce a system of road management and set up measures for the technological process. This is the efficient management of the limited financial resources of the owner of the roads as the focal point for the future.

The design of the backbone road network is crucial for increasing the efficiency of the funds spent, which comprise a large part of the expenditure within the regional budget. It is these budgets that are often enormously burdened with expenditure on the construction and maintenance of transport infrastructure while their income, according to many opinions, is inadequate. Discussions are usually about the breakdown of fuel and grease tax revenue or road tax. A systemic management solution is a strategic decision that is particularly important in terms of planning and financing the road network in the long run. In this contribution, the issue of public transport, which is realised after these roads, was briefly omitted. Public transport is one of the aspects of addressing unemployment in some parts of the districts where it is desirable to ensure sufficient mobility for the population in order to reverse this situation. High-quality transport connections and connections to the backbone road and motorway network are one of the decisive factors for placing a significant investment, as many companies prefer freight transport exclusively on the road, often in the Just in Time system. In terms of the structure of the national economy, the condition of the transport infrastructure is a limiting factor for the whole economy, and therefore attention needs to be paid to this issue.

Due to its location in the Czech Republic, the Vysočina Region can benefit from its connection to the most important highway passing through the Czech Republic although it is necessary to also pay close attention to the lower class roads. In this respect, not only to the efficient and economical maintenance of roads, as discussed in this article, but also to the construction of new roads and bypasses for municipalities in view of increasing traffic density and safety aspects. The interconnection of each impact on transport infrastructure is important to mention as a whole. For example, public transport is often the factor that is historically crucial, particularly in the planning of winter maintenance. However, other influences, in particular, political decisions, when large investment and lobbying become the subject of pre-election campaigns, are often affected by transport infrastructure. In connection with the issue, the possibility of imposing a charge on these roads, especially for heavy goods vehicles, is often discussed. It is this decision that can have a significant impact on maintenance issues due to the potential changes in traffic density on individual roads. 


\section{References}

Abraham, A. (2014). Sustainable Development and the Environment. Hamburg: Anchor Academic Publishing.

Behrends, S. (2017). Burden or Opportunity for Modal Shift? - Embracing the Urban Dimension of Inter Modal Road-Rail Transport. Transport Policy, 59(10), pp. 10-16, https://doi.org/10.1016/j.tranpol.2017.06.004

General Directorate for National Roads and Motorways (DNRM), (2016). Nationwide Traffic Aggregation of the Traffic Intensity - Vysočina Region. [online] Available at: http://scitani2016.rsd.cz/pages/results/section/default.aspx?l=kraj\%20Vyso\%C4\%8Dina [Accessed 19 Sep. 2017].

Černý, M. (2015). The Economic Optimalization of the Road Network in the Vysočina Region. PhD. Mendel University, Brno.

Dubrovsky, V., Yaroshevich, N. and Kuzmin, E. (2016). Transactional Approach in Assessment of Operational Performance of Companies in Transport Infrastructure. Journal of Industrial Engineering and Management, 9(2), pp. 389-412, https://doi.org/10.3926/jiem.1721

Dvořák, P. (2008). Veřejné finance, fiskální nerovnováha a finanční krize [Public Finance, Fiscal Imbalances and Financial Crisis]. Praha: Beck.

Heinen, E. et al. (2015). Changes in Mode of Travel to Work: A Natural Experimental Study of New Transport Infrastructure. The International Journal of Behavioral Nutrition and Physical Activity, 12(1), https://doi.org/10.1186/s12966-015-0239-8

Janatka, F. (2017). Podnikání v globalizovaném světě [Business in a Globalized World]. Prague: Wolters Kluwer.

Jazcilevich, A. et al. (2015). Economic-Environmental Analysis of Traffic-calming Devices. Transportation Research Part D: Transport and Environment, 36(5), pp. 86-95, https://doi.org/10.1016/j.trd.2015.02.010

Koblížek, R. (2016). Poptávková doprava - Dispečink hromadné dopravy [Demand-Responsive Transport - Public Transport Dispatching]. [online] Available at: http://www.hromadnado-prava.cz/poptavkova_doprava.htm [Accessed 22 Apr. 2017].

Krbová, J. (2016). Strategické plánování ve veřejné správě [Strategic Planning in Public Sphere]. Prague: Wolters Kluwer.

Kruntorádová, I. (2015). Politické aspekty financování českých měst [Political Aspects of the Czech Municipal Funding]. Prague: Carolinum Publishing House.

Ksusv.cz, (2015). Regional Road Administration and Maintenance of the Vysočina Region's Official Website. [online] Available at: http://www.ksusv.cz [Accessed 3 Jan. 2015].

Matas, A., Raymond, J.-L. and Roig, J.-L. (2015). Wages and Accessibility: The Impact of Transport Infrastructure. Regional Studies, 49(7), pp. 1236-1254, https://doi.org/10.1080/00343404.2013.827336

Myczko, Ł. et al. (2017). Effects of Local Roads and Car Traffic on the Occurrence Pattern and Foraging Behaviour of Bats. Transportation Research Part D: Transport and Environment, 56(10), pp. 222-228, https://doi.org/10.1016/j.trd.2017.08.011

Newman, P. and Kenworthy, J. R. (2015). The End of Automobile Dependence: How Cities Are Moving beyond Car-based Planning. Washington, DC: Island Press.

Pawlasová, P. (2015). The Factors Influencing Satisfaction with Public City Transport: A Structural Equation Modelling Approach. Journal of Competitiveness, 7(4), pp. 18-32, https://doi.org/10.7441/joc.2015.04.02 
Roumboutsos, A., Voordijk, H. and Pantelias, A., eds., (2015). Funding and Financing Transport Infrastructure: Business Models to Enhance and Enable Financing of Infrastructure in Transport. New York: Routledge.

Sachs, J. (2015). The Age of Sustainable Development. New York: Columbia University Press.

Sellers, J. et al. (2017). Inequality and Governance in the Metropolis: Place Equality Regimes and Fiscal Choices in Eleven Countries. Basingstoke: Palgrave Macmillan.

Simoni, M. D. and Claudel, Ch. G. (2017). A Fast Simulation Algorithm for Multiple Moving Bottlenecks and Applications in Urban Freight Traffic Management. Transportation Research Part B: Methodological, 104(10), pp. 238-255, https://doi.org/10.1016/j.trb.2017.06.010

Solecka, K. and Żak, J. (2014). Integration of the Urban Public Transportation System with the Application of Traffic Simulation. Transportation Research Procedia, 3, pp. 259-268, https://doi.org/10.1016/j.trpro.2014.10.005 